\title{
PERAN TEKNOLOGI DALAM PEMBELAJARAN DI MASA PANDEMI COVID-19
}

\author{
Unik Hanifah Salsabila \\ Universitas Ahmad dahlan \\ Jl. Ringroad Selatan, Daerah istimewa Yogyakarta \\ unik.salsabila@pai.uad.ac.id \\ Lailli Irna Sari \\ Universitas Ahmad Dahlan \\ Jl. Ringroad Selatan. Daerah Istimewa Yogyakarta \\ lailli1800031155@webmail.uad.ac.id \\ Khusna Haibati Lathif \\ Universitas Ahmad Dahlan \\ Jl. Ringroad Selatan, Daerah Istimewa Yogyakarta \\ khusna1800031117@webmail.uad.ac.id \\ Ayu Puji Lestari \\ Universitas Ahmad dahlan \\ Jl. Ringroad Selatan, Daerah Istimewa Yogyakarta \\ ayu1800031150@webmail.uad.ac.id \\ Asyharinur Ayuning \\ Universitas Ahmad Dahlan \\ Jl. Ringroad Selatan, Daerah Istimewa Yogyakarta \\ asyharinur1800031027@webmail.uad.ac.id
}

DOI: 10.46781/al-mutharahah.v17i2.138

\begin{abstract}
The Covid-19 pandemic has caused major changes in almost all aspects of life, one of which is the education system. Changes in the education system make it difficult for students to receive the material, especially students at the Elementary School and Kindergarten levels, because learning that is usually done conventionally turns into distance-learning or done online, the implementation of which cannot be separated from the use of technology information. This journal aims to examine the role of technology in the implementation of learning during the Covid-19 pandemic, besides that it also examines the challenges of education during the Covid19 pandemic using descriptive-analytical literature methods. The results and conclusions in this paper show that technology has an important role in the implementation of learning, especially during the Covid-19 pandemic like today. Technology plays a role as a medium in making interactions between educators and students in the implementation of online learning. In addition, technology also plays a role in facilitating educators to deliver learning material so that learning continues even though it is not done face to face. In the implementation of online learning, of course, there are obstacles that become challenges for educations actors, related to academic culture, including values, attitudes, knowledge, skills, and readiness of technologyrelated facilities and infrastructure. The implementation of literacy and training related to the
\end{abstract}


use of technology can be a solution to facing some of the challenges of online learning during the current Covid-19 pandemic.

Keywords: Technology; Education; Covid-19 Pandemic

\begin{abstract}
Abstrak
Pandemi Covid-19 menyebabkan adanya perubahan-perubahan besar hampir diseluruh aspek kehidupan salah satunya pada sistem pendidikan. Perubahan sistem pendidikan menyebabkan para siswa menjadi sulit untuk menerima materi, terlebih para siswa di jenjang Sekolah Dasar dan Taman Kanak-kanak, dikarenakan pembelajaran yang biasanya dilakukan secara konvensional berubah menjadi pembelajaran jarak jauh atau dilakukan secara daring, yang pelaksanaannya tidak dapat terlepas dari pemanfaatan teknologi informasi. Jurnal ini bertujuan untuk mengkaji bagaimana peran teknologi dalam pelaksanaan pembelajaran selama masa pandemi Covid-19, selain itu juga mengkaji mengenai tantangan pendidikan selama masa pandemi Covid-19 dengan menggunakan metode literatur bersifat deskriptif-analitis. Hasil dan kesimpulan dalam penulisan ini menunjukkan bahwa, teknologi memiliki peran yang penting terhadap pelaksanaan pembelajaran terlebih di saat pandemi Covid-19 seperti saat ini. Teknologi berperan sebagai media dalam melakukan interaksi antara pendidik dan peserta didik dalam pelaksanaan pembelajaran daring. Selain itu teknologi juga berperan dalam memfasilitasi pendidik untuk menyampaikan materi pembelajaran sehingga pembelajaran tetap berlangsung meskipun tidak dilakukan secara tatap muka langsung. Dalam pelaksanaan pembelajaran daring tentunya terdapat hambatan yang menjadi tantangan tersendiri bagi para pelaku pendidikan, yang berkaitan dengan budaya akademik, meliputi nilai, sikap, pengetahuan, keterampilan, serta kesiapan sarana dan prasarana terkait teknologi. Penyelenggaraan literasi serta pelatihan berkaitan dengan pemanfaatan teknologi dapat menjadi salah satu solusi dalam menghadapi beberapa tantangan pembelajaran daring selama pandemi Covid-19 saat ini.
\end{abstract}

Kata Kunci: Teknologi; Pendidikan; Pandemi Covid-19

\title{
A. PENDAHULUAN
}

Saat ini hampir setiap negara di belahan dunia sedang dilanda wabah Covid-19. Covid-19 merupakan virus yang penyebarannya sangat cepat dan merupakan virus yang mematikan, untuk itu negara-negara di dunia disibukkan dalam menetapkan berbagai kebijakan sebagai upaya dalam memutus rantai penyebaran virus corona, salah satunya Indonesia. Indonesia sendiri menetapkan kebijakan Pembatasan Sosial Berskala Besar (PSBB) yang diberlakukan disetiap daerah. Kebijakan tersebut menjadikan adanya perbahan-perubahan besar, seperti bidang ekonomi, bidang kesehatan, maupun bidang pendidikan. ${ }^{1}$

Dalm bidang pendidikan, pemerintah melalui Kementerian Pendidikan dan Kebudayaan (Kemendikbud) berupaya agar para pelaku pendidikan seperti pendidik dan peserta didik tetap bisa menyelenggarakan belajar mengajar meskipun dengan cara yang berbeda. Kemendikbud menetapkan peraturan bahwa pendidikan di Indonesia tetap diselenggarakan, namun dengan sistem yang berbeda yaitu Study From Home $(\mathrm{SFH}){ }^{2}$ Kementerian pendidikan dan kebudayaan mendorong pelaksanaan proses belajar mengajar dilakukan secara daring. Hal tersebut sesuai dengan Surat Edaran Kemendikbud RI nomor 3 tahun 2020 mengenai pencegahan Corona Virus Disease (COVID-19) pada satuan Pendidikan, dan Surat Sekjen Mendikbud nomor 35492/

${ }^{1}$ Khamim Zarkasih Putro et al., "Pola Interaksi Anak Dan Orangtua Selama Kebijakan Pembelajaran Di Rumah," Fitrah: Journal of Islamic Education (FJIE) 1, no. 1 (2020): 126, https://jurnal.staisumateramedan.ac.id/index.php/fitrah/article/view/12/8.

2 Putro et al. 
A.A5/ HK/ 2020 tanggal 12 Maret 2020 perihal Pencegahan Penyebaran Corona Virus Disease (COVID-19). ${ }^{3}$

Dalam pelaksanaan pembelajaran daring memberikan tantangan tersendiri bagi pelaku pendidikan, seperti pendidik, peserta didik, institusi dan bahkan memberikan tantangan bagi masyarakat luas seperti para orang tua. Dalam pelaksanaannya pendidik harus mencari cara bagaimana agar tetap bisa menyampaikan materi pembelajaran dan dapat diterima dengan mudah oleh peserta didik. Begitu juga peserta didik yang dituntut agar bisa menyesuaikan diri dalam situasi dan kondisi seperti saat ini, salah satunya kesiapan mental. ${ }^{4}$

Dalam pelaksanaannya pembelajaran daring tentunya tidak dapat terlepas dari peran teknologi. Teknologi dapat mempermudah segala kebutuhan dalam proses belajar mengajar. Sejalan dengan pendapat Tounder et al (dalam Selwyn, 2011) yang mengatakan bahwa tenologi digital dalam lembaga pendidikan sebagai sarana pendukung dalam pembelajaran, baik sebagai sarana dalam mengakses informasi sumber belajar ataupun sebagai sarana penunjang kegiatan belajar dan berkaitan dengan tugas. ${ }^{5}$ Seiring dengan perkembangan zaman teknologi semakin berkembang, saat ini banyak platform yang dapat membantu pelaksaan pembelajaran daring seprti $e$-learing, Google Clasroom, Edmodo, Moodle, Rumah belajar, dan bahkan platform dalam bentuk video conference sudah semakin banyak diantaranya seperti Google meet, Zoom, dan Visco Webex.

Sebelumnya kajian berkaitan dengan peranan teknologi dalam pendidikan seperti ini sudah banyak dilakukan salah satunya oleh Rogantina (2017), yang menjelaskan bahwa teknologi sangat berperan dalam meningkatkan mutu pendidikan. selain itu peran teknologi dapat meningkatkan efektifitas dan efisiensi proses belajar mengajar sehingga dapat mempermudah dalam mencapai tujuan pendidikan. ${ }^{6}$ Meskipun kajian ini terlihat serupa dengan kajian sebelumnya, dengan kondisi seperti saat ini dimana adanya pandemi Covid-19 yang berpengaruh besar terhadap psikologi pembelajaran yang menjadikan kajian ini berbeda. Selain itu subjek yang berhadapan dengan teknologi ini pun berbeda, sehingga terdapat hal baru yang mendukung kajian sebelumnya. Beradasarkan uraian tersebut, tulisan ini akan mengkaji mengenai bagaimana peran teknologi dalam pembelajaran serta tantangan pendidikan yang dihadapi selama masa pandemi Covid-19 saat ini.

\footnotetext{
${ }^{3}$ Ni Komang Suni Astini, “Tantangan Dan Peluang Pemanfaatan Teknologi Informasi Dalam Pembelajaran Online Masa Covid-19," Cetta: Jurnal Ilmu Pendidikan 3, no. 2 (2020): 243, https://doi.org/10.37329/cetta.v3i2.452.

4 Abdul Latip, “Komunikasi Pada Pembelajaran Jarak Jauh Di Masa Pandemi COVID-19,” Edukasi Dan Teknologi 1, no. $\quad 2 \quad$ (2020): https://www.researchgate.net/profile/Abdul_Latip/publication/341868608_PERAN_LITERASI_TEKNOLOGI_ INFORMASI_DAN_KOMUNIKASI_PADA_PEMBELAJARAN_JARAK_JAUH_DI_MASA_PANDEMI_C OVID-19/links/5ed773c245851529452a71e9/PERAN-LITERASI-TEKNOLOGI-INFORMASI-DANKOMUNIKASI.

${ }^{5}$ Sudarsri Lestari, "Peran Teknologi Dalam Pendidikan Di Era Globalisasi," Edureligia; Jurnal Pendidikan Agama Islam 2, no. 2 (2018): 95-96, https://doi.org/10.33650/edureligia.v2i2.459.

${ }^{6}$ Rogantina Meri Andri, "Peran Dan Fungsi Teknologi Dalam Peningkatan Kualitas Pembelajaran," Jurnal Ilmiah Research Sains 3, no. 1 (2017): 122-29, http://www.jurnalmudiraindure.com/wpcontent/uploads/2017/04/PERAN-DAN-FUNGSI-TEKNOLOGI-DALAM-PENINGKATAN-KUALITASPEMBELAJARAN.pdf.
} 


\section{B. METODE}

Kajian ini menggunakan metode literatur yang bersifat deskriptif-analitis. Menurut (Sugiono: 2009; 29) deskriptif-analitis merupakan metode yang mendeskripsikan atau menggambarkan suatu objek yang diteliti melalui data atau sampel yang telah dikumpulkan apa adanya tanpa melakukan analisis dan membuat kesimpulan yang berlaku untuk umum. Sedangkan menurut Burhan Bungin (2008) "metode literatur merupakan salah satu metode pengumpulan data yang digunakan dalam metodologi penelitian sosial untuk menelusuri data rekam peristiwa". Literatur yang digunakan dalam kajian ini bersumber dari artikel, buku dan jurnal online yang berkaitan dengan judul kajian. Adapun langkah-langkah yang dilakukan dalam kajian literatur ini diantaranya mendefinisikan ruang lingkup topik yang akan di review, mengidentifikasikan sumber-sumber yang relevan, mereview literatur, menulis literatur dan mengaplikasikan literatur pada kajian yang akan dilakukan. ${ }^{7}$

\section{PEMBAHASAN}

Pendidikan merupakan salah satu tombak berkembangnya suatu negara, menciptakan generasi-generasi yang beradab, memiliki intelektual yang tinggi juga mampu membangun negara. Pendidikan menjadi kunci dalam mengisi tujuan hidup bangsa yang merdeka. Pendidikan dapat memberikan berbagai perubahan positif terhadap manusianya. Perubahan tersebut dapat diperoleh apabila dalam pelaksanaan pendidikan dilakukan secara tepat. Pelaksaan pendidikan di Indonesia belum bisa dikataka tepat, salah satu problem pendidikan di Indonesia terletak pada persoalan pemerataan pendidikan. Saat ini masih ada beberapa kalangan masyarakat Indonesia yang belum memperoleh pendidikan yang layak, ditambah saat ini seluruh dunia sedang dilanda musibah, yaitu mewabahnya virus Covid-19. ${ }^{8}$

Pasca pandemi Covid-19 masuk ke Indonesia, terhitung dari bulan Maret 2020 sebagai upaya dalam menekan angka penularan virus Covid-19, pemerintah menetapkan kebijakan yaitu, meniadakan semntara pembelajaran tatap muka yang kemudian diganti dengan Pembelajaran Jarak Jauh (PJJ). Berbagai upaya dilakukan agar aktivitas pendidikan tetap terlaksana. Salah satu upaya pemerintah dalam program Pembelajaran Jarah Jauh (PJJ) yaitu dengan menyajikan materi pelajaran sesuia dengan jenjang pendidikan melalui media elektronik televisi yang disiarkan di stasiun TVRI. Program ini disajikan untuk jenjang taman kanak-kanak (TK), Sekolah Dasar (SD), Sekolah Menengah Pertama (SMP), dan Sekolah Menengah Atas (SMA).

Dalam pelaksanaan Pembelajaran Jarak Jauh ini tentu memiliki kelebihan maupun kekurangan. Kelebihan dari pelaskaan PJJ ini menjadikan pendidik maupun peserta didik saling berinovasi dan juga memanfaatkan teknologi dalam pembelajaran. Sedangkan kekurangan dalam pelaksanan PJJ ini terletak pada kendala ekonomi, ketidak meratanya internet dan teknologi yang memadai, juga pembelajaran harus dilakukan dengan berkelanjutan agar peserta didik memahami dengan baik dan benar.

\section{Pengertian Tenologi Pendidikan}

Secara historis bidang teknologi pendidikan lahir di Amerika Serikat yang pada saat itu sedang terlibat Perang Dunia II, sehingga memerlukan personel militer yang terampil dalam mengoperasikan peralatan perang, maka dari itu dibutuhkan pelatihan yang efektif. Pelatihan tersbut kemudia dikembangakan dengan memanfaatkan berbagai media dan simulator untuk meningkatkan kinerja personel

${ }^{7}$ Titik Rahayu et al., “Teknik Menulis Review Literatur Dalam Sebuah Artikel IImiah,” no. September (2019), https://doi.org/10.31227/osf.io/z6m2y.

8 Meylan Saleh, "Merdeka Belajar Di Tengah Pandemi Covid-19," in Prosiding Seminar Nasional Hardiknas, 2020, 51, http://proceedings.ideaspublishing.co.id/index.php/hardiknas/article/view/8/8. 
militer, yang kemudian dikenal dengan istilah teknologi kinerja (performance technology). Pada saat itu perkembangan teknologi berkaitan erat dengan perkembangan ilmu pengetahuan dan teknologi yang dimanfaatkan untuk mewujudkan kegiatan pembelajaran yang efektif dan efisien. ${ }^{9}$

Pada hakikatnya teknologi pendidikan mencakup upaya-upaya yang dapat bermanfaat untuk menciptakan proses pembelajran yang efektif dan efisien pada setiap individu. Hal ini sejalan dengan definisi teknologi pendidikan terbaru yang dikemukakan oleh The Association of Educational Communication and Technology - the AECT - yaitu: teknologi pendidikan dapat didefinisikan sebagai "...sebuah studi dan praktek etis yang digunakan untuk memfasilitasi berlangsungnya proses belajar dan memperbaiki kinerja memalui penciptaan, penggunaan, pengelolaan proyek, teknologi dan sumber daya yang tepat". ${ }^{10}$

Dalam Kamus Besar Bahasa Indonesia (KBBI), teknologi pendidikan adalah "metode bersistem untuk merencanakan menggunakan, dan menilai seluruh kegiatan pengajaran dan pembelajaran dengan memperhatikan, baik sumber teknis maupun manusia dan interaksi antara keduanya, sehingga mendapatkan bentuk pendidikan yang lebih efektif". ${ }^{11}$ Sedangkan menurut Kandung (2014), teknologi pendidikan adalah suatu teori dan praktik dengan maksud membantu jalannya pembelajaran serta meningkatkan performa dengan menyusun, memanfaatkan, dan mengolah terkait proses serta sumber teknologi yang memadai. Teknologi pendidikan menjadi perantara dalam membantu jalannya proses pendidikan dengan maksud mencapai efektifitas, efisien, dan keberhasilan. ${ }^{12}$

Sedangkan menurut Tahir (2016) teknologi pendidikan merupakan suatu proses strategi terpadu dalam upaya memecahkan masalah pembelajaran. ${ }^{13}$ Pendapat tersebut sependapat dengan Muffoletto dalam Selwyn (2011) yang berpendapat bahwa teknologi pendidikan bukan mengenai alat melainkan mengenai proses serta sistem yang mengarah pada hasil yang ingin dicapai. Selanjutnya Lestari (2018) berpendapat bahwa teknologi pendidikan merupakan sistem yang digunakan sebagai penunjang pembelajaran sehingga tercapai hasil yang diinginkan. Jadi dapat dikatakan bahwa teknologi pendidikan merupakan segala upaya yang dimaksud untuk memecahkan persoalan-persoalan terkait dengan pembelajaran. ${ }^{14}$

\footnotetext{
9 Yusufhadi Miarso, Menyemai Benih Teknologi Pendidikan (Jakarta: Prenadamedia Group, 2016), https://books.google.co.id/books?id=rhVNDwAAQBAJ\&printsec=frontcover\&dq=buku+menyemai+benih+tekn ologi+pendidikan\&hl=id\&sa=X\&ved=2ahUKEwiTh_ez--

3sAhWDILcAHfoLCjgQ6AEwAHoECAUQAg\#v=onepage\&q=buku menyemai benih teknologi pendidikan $\& \mathrm{f}=$ false.

${ }^{10}$ Benny A. Pribadi, "Peranan Teknologi Pendidikan Dalam Meningkatkan Kualitas Pembelajaran," in Optimalisasi Peranan Teknologi Pendidikan Dalam Peningkatan Kualitas Pembelajaran (Padang: Universitas Terbuka Repository, 2011), 2-3, http://repository.ut.ac.id/7265/1/Peranan Teknologi Pendidikan dalam.pdf.

11 Badan Pengembangan dan Pembinaan Bahasa Kemendikbud, "KBBI Daring: Pencarian," 2016, https://kbbi.kemdikbud.go.id/.

${ }^{12}$ Kristiana Hesti Padmini and Brigitta Putri Atika Tyagita, "Teknologi Pendidikan Sebagai Pembelajaran Kompetitif Untuk Meningkatkan Prestasi Siswa: Studi Kasus Di Salah Satu SMA Di Salatiga," in Prosiding Seminar Nasional Pendidikan (Surakarta, 2015), 60, https://media.neliti.com/media/publications/171192-IDteknologi-pendidikan-sebagai-pembelajara.pdf.

${ }^{13}$ M. Yusuf Tahir, "Peranan Teknologi Pendidikan Dalam Peningkatan Mutu Pendidikan," in Prosiding SIDKUN 2016: Seminar Islam Dan Kelestarian Ummah Peringkat Serantau (Kedah: Pusat Pengaji Bahasa, Tamadun dan Falsafah, Kolej Sastera Sains, Universitas Utara Malaysia, 2016), 484-89,

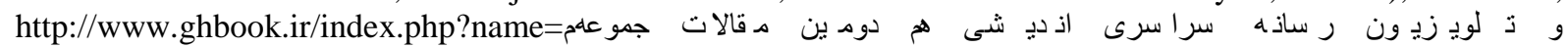
سد كو لاري سم سم \&option=com_dbook\&task=readonline\&book_id=13629\&page=108\&chkhashk=03C706812F\&Ite mid=218\&lang=fa\&tmpl=component.

${ }^{14}$ Lestari, "Peran Teknologi Dalam Pendidikan Di Era Globalisasi."
} 


\section{Peran teknologi Pendidikan di Masa Pandemi Covid-19}

Berdasarkan pengertian yang telah dibahas sebelumnya teknologi pendidikan memberikan manfaat dalam menunjang keberhasilan pembelajaran. Peran teknologi pendidikan diantaranya sebagai berikut: (1) teknologi pendidikan sebagai alat pendukung desain pengetahuan, (2) teknologi pendidikan sebagai sarana informasi untuk mencari tahu pengetahuan yang mendukung peserta didik, (3) teknologi pendidikan sebagai media dalam memfasilitasi peserta didik dalam mengemukakan argumen, (4) teknologi pendidikan mampu meningkatkan efektivitas dan efisiensi proses pembelajaran, (5) teknologi pendidikan sebagai alat bantu untuk mencapai tujuan pendidikan.

Disamping itu peran teknologi pendidikan menjadi sangat penting dalam proses pembelajaran, terlebih pada masa pandemi seperti saat ini. Munculnya Covid-19 mengaharuskan segala aktivitas dilakukan di rumah, termasuk kegiatan belajar mengajar. sebagai bentuk upaya pemutusan rantai penularan virus Covid19 , kegiatan pembelajaran yang semula dilakuakn secara tatap muka langsung oleh pendidik dan peserta didik dilakukan secara daring.

Dengan begitu teknologi menjadi bagian terpenting dalam membantu proses pembelajaran daring. Sehubungan dengan hal tersebut Buselic M., Tavakcu T., et al dalam (Latip, 2020) menegaskan bahwa inti dari pelaksaan pembelajaran daring adalah bagaimana cara memilih metode pembelajaran yang tepat dengan dibantu teknologi yang bermaksud menyampaikan materi pembelajaran kepada peserta didik meskipun tidak bertemu dengan tatap muka secara langsung seperti halnya pembelajaran konvensional. ${ }^{15}$ Dengan kata lain teknologi berperan sebagai media interaksi serta transfer informasi terkait pembelajaran dalam pelaksanaan pembelajaran daring.

Sebagai perangkat lunak atau software, teknologi berperan besar dalam pembelajaran terutama di situasi pandemi Covid-19 seperti saat ini. Teknologi memberikan kemudahan kepada pendidik serta peserta didik dalam melakukan pembelajaran jarak jauh. Berbagai macam platform disediakan dengan maksud mempermudah pelaksanaan pembelajaran jarak jauh, diantaranya mempermudah pendidik dalam melakukan penilaian terhadap peserta didik meskipun tidak dilakukan secara tatap muka langsung, dengan memanfaatkan berbagai platform seperti, google document sebagai media dalam melakukan forum diskusi online, melakukaan submit ujian melalui google form, serta pengadaan kuis melalui website ataupun aplikasi. Teknologi juga membantu peserta didik dalam memperoleh materi-materi pelajaran yang kemungkinan tidak di peroleh selama pembelajaran jarak jauh berlangsung dengan mengakses berbagai macam website serta aplikasi seperti, edutafsi.com, wolframalpha.com, slide share, inspigo dan masih banyak lagi. Selain itu teknologi juga berperan dalam meningkatkan kreativitas pendidik maupun peserta didik, pendidik dapat berinovasi dalam penyampaian materi pembelajaran dengan memanfaatkan berbagai situs media sosial seperti Facebook, Instagram, YouTube, dan lain sebagainya. Sama halnya dengan pendidik, peserta didik dapat memanfaatkan berbagai situs media sosial dalam memenuhi tugas yang diberikan. Dalama hal ini teknologi dapat memberikan manfaat dalam menunjang keberhasilan pembelajaran daring di tengah pandemi seperti saat ini.

Keberhasilan pembelajaran daring tidak hanya dipengaruhi dari peran teknologi internet saja, tetapi juga dipengaruhi dari kualitas Sumber Daya Manusia. Teknologi internet tidak akan memberikan pengaruh yang signifikan apabila SDM

\footnotetext{
${ }^{15}$ Latip, "Komunikasi Pada Pembelajaran Jarak Jauh Di Masa Pandemi COVID-19.”
} 
sebagai operator atau pengguna tidak memiliki pengetahuan serta keterampilan yang baik dalam penggunaan dan pengelolaan teknologi. Untuk itu pemahaman megenai teknologi menjadi faktor utama dalam keberhasilan pembelajaran daring. Teknologi internet dalam pembelajaran daring berperan sangat penting, dikarenakan tanpa adanya teknologi internet dapat menghambat pembelajaran yang dilakukan secara online. Teknologi internet juga berpengaruh bagi siswa atau mahasiswa untuk mencari bahan pembelajaran yang kurang mereka pahami. Teknologi internet dapat memberikan manfaat yang banyak dalam menunjang kegiatan pembelajaran.

3. Tantangan Pendidikan di Masa pandemi Covid-19

Wabah Covid-19 membawa dampak besar terhadap beberapa sektor, salah satunya sektor pendidikan. sebagai upaya pencegahan penularan virus corona, hampir seluruh negara menerapkan berbagai kebijakan yaitu salah satunya memberlakukan physical distancing. Pemerintah Indonesia sendiri memberlakukan Pembatasan Sosial Berskala Besar (PSBB) yang dimana mengharuskan segala aktivitas dikerjakan di dalam rumah. Mulai dari aktivitas pekerjaan sampai aktivitas pembelajaran pun dilakukan di rumah, dengan maksud untuk mengurangi interaksi antar manusia dalam upaya pencegahan penyebaran virus vorona.

Berdasarkan kebijakan tersebut maka dengan terpaksa kegiatan pembelajaran dilakasanakan secara daring. Pembelajaran daring merupakan sistem pembelajaran yang pelaksanaannya tidak dilakukan secara langsung dalam satu tempat yang sama, melaikan dilakukan dengan memanfaatkan platform yang dapat membantu proses jalannya belajar mengajar meskipun dilakukan secara jarak jauh. ${ }^{16}$ Seiring pesatnya perkembangan teknologi, komunikasi dan informasi, pembelajaran daring dapat dilakukan dengan menggunakan berbagai platform seperti e-learning, Google Clasroom, rumah belajar, dan lain sebagainya. Selain itu pembelajaran daring dapat dilakukan dalam bentuk video conference dengan menggunakan beberapa platform diantaranya seperti aplikasi zoom, google meet, dan visco webex. Selain memanfaatkan aplikasi-aplikasi tersebut tidak jarang Whatsapp Group menjadi alternatif dalam pelaksanaan pembelajaran daring. ${ }^{17}$

Dalam pelaksanaan pembelajaran daring di masa pandemi saat ini tentu menghadirkan berbagai hambatan. Hambatan itulah yang menjadi tantangan tersendiri bagi pelaku dalam dunia pendidikan, khususnya bagi pendidik dan peserta didik, mengingat pelaksanaan pembelajaran daring harus tetap diselenggarakan ditengah wabah Covid-19. ${ }^{18}$ Pembelajaran daring sendiri dalam pelaksanaannya tidak dapat terlepas dari dari jaringan internet, maka sudah menjadi hal yang lumrah bahwa hambatan dalam pelaksanaan pembelajaran daring ini adalah akses jaringan internet yang belum merata. Hal ini dibuktikan oleh Jamalul Izza, selaku ketua umum Asosiasi Penyelenggaraan Jasa Internet Indonesia (APJII), yang menjelaskan bahwa Indonesia memiliki sekitar 74 ribu desa, yang diantaranya masih banyak desa yang tidak bisa menikmati jaringan internet seperti daerahdaerah lainnya. Hal tersebut dilatarbelakangi salah satunya faktor letak geografis

${ }^{16}$ Oktafia Ika Handarini and Siti Sri Wulandari, "Pembelajaran Daring Sebagai Upaya Study From Home (SFH) Selama Pandemi Covid 19," Jurnal Pendidikan Administrasi Perkantoran (JPAP) 8, no. 3 (2020): 498, https://journal.unesa.ac.id/index.php/jpap/article/view/8503.

${ }^{17}$ Latip, "Komunikasi Pada Pembelajaran Jarak Jauh Di Masa Pandemi COVID-19."

${ }^{18}$ Fieka Nurul Arifa, "Tantangan Pelaksanaan Kebijakan Belajar Dari Rumah Dalam Masa Darurat Covid19," Info Singkat;Kajian Singkat Terhadap Isu Aktual Dan Strategis XII, no. 7/I (2020): 15, http://berkas.dpr.go.id/puslit/files/info_singkat/Info Singkat-XII-7-I-P3DI-April-2020-1953.pdf. 
Indonesia yang terdiri dari ribuan pulau. ${ }^{19}$ Selain itu wabah Covid-19 memaksa berbagai aspek untuk melakukan penyesuaian-penyesuaian terhadap kondisi kondisi dan situasi yang baru. Dalam lingkup pendidikan, baik pendidik maupun peserta didik dituntut untuk bisa mengoperasikan sistem pembelajaran secara online dengan baik. Kesiapan Sumber Daya Manusia menjadi bagian terpenting dalam mencapai keberhasilan pembelajaran online, kesiapan ini berkaitan dengan kemampuan pendidik dan peserta didik dalam menggunakan dan mengolah berbagai sistem teknologi yang dimanfaatkan dalam jalannya pembelajaran daring. ${ }^{20}$ Transformasi model pembelajaran secara tiba-tiba yang bermula dari model konvensional menjadi berbasis online mengakibatkan kurangnya persiapan yang matang sehingga pembelajaran online saat ini belum bisa dikatakan optimal. Hal tersebut menjadi tantangan tersendiri bagi pendidik dan peserta didik agar bisa segera menyesuiakan diri terhadap kondisi dimana keahlian dalam mengoperasikan sistem teknologi sudah menjadi suatu kebutuhan yang penting di masa pandemi saat ini.

Disamping itu hambatan dalam pembelajaran daring datang dari peserta didik. semangat belajar peserta didik selama proses pembelajaran daring menurun dibandingkan ketika pembelajaran tatap muka langsung. Berdasarkan penelitian yang sudah dilakukan sebelumya oleh Adhetya Cahyani, Iin Diah Listiani, \& Sari Puteri Deta Larasati (2020) menunjukkan bahwa motivasi belajar peserta didik yang mengikuti pembelajaran daring selama pandemi menurun. Penurunan motivasi belajar peserta didik dipengaruhi oleh beberapa faktor, salah satunya yaitu kondisi selama pembelajaran daring yang mewajibkan peserta didik untuk belajar di rumahnya masing-masing, sehingga memaksa mereka untuk mempelajari serta memahami materi pelajaran secara mandiri, pendidik tidak dapat mendampingi dan mendidik peserta didik secara langsung, sehingga pendidik tidak dapat melakukan tindakan seperti pemberian reward-punishment, pemberian motivasi, menegur, dan lain sebagainya. Sedangkan tindakan-tindakan pendidik tersebut yang dapat menguatkan motivasi peserta didik. selain itu efektivitas waktu belajar juga mempengaruhi motivasi belajar peserta didik. Peserta didik merasa sulit dalam menetukan waktu yang tepat untuk belajar di rumah. Lingkungan sosial keluarga yang kurang kondusif menyebabkan peserta didik tidak dapat fokus untuk belajar. ${ }^{21}$ Melihat hambatan tersebut menjadi tantangan tersendiri bagi pendidik maupun peserta didik. pendidik diharuskan lebih berinovasi dalam mennetukan cara atau metode dalam menyampaikan materi agar peseta didik mampu menerima materi dengan mudah meski tidak disampaikan secara tatap muka langsung. Sedangkan peserta didik dituntut agar bisa beradaptasi dengan kondisi dan situasi seperti saat ini. Secara garis besar tantangan pendidikan selama pandemi Covid-19 menyangkut budaya akademik, yang meliputi nilai, sikap, pengetahuan, keterampilan, serta kesiapan sarana dan prasarana yang berkaitan dengan literasi teknologi.

\section{Isu-Isu Teknologi Pendidikan di Masa Pandemi Covid-19}

Teknologi merupakan suatu yang tercipta dari manusia, diciptakan untuk memenuhi kebutuhan manusia dan meningkatkan kualitas manusia. Teknologi pendidikan hadir untuk mempermudah perkembangan dalam pendidikan, beberapa

\footnotetext{
19 Juanda, “APJII: Indonesia Belum Merdeka Internet," KOMITE.ID, 2020, https://www.komite.id/2020/08/11/apjii-indonesia-belum-merdeka-internet/.

${ }^{20}$ Latip, "Komunikasi Pada Pembelajaran Jarak Jauh Di Masa Pandemi COVID-19."

${ }^{21}$ Adhetya Cahyani, Iin Diah Listiana, and Sari Puteri Deta Larasati, "Motivasi Belajar Siswa SMA Pada Pembelajaran Daring Di Masa Pandemi Covid-19," IQ (Ilmu Al-Qur'an): Jurnal Pendidikan Islam 3, no. 01 (2020): 137, https://doi.org/10.37542/iq.v3i01.57.
} 
hal yang masih menjadi suatu hal yang rancu dalam keseharian kita. Terlebih pada masa pandemi saat ini, media yang digunakan sebagian banyak pada akses internet dan penggunaan smartphone. Dalam penggunaanya teknologi pendidikan menghadirkan beberapa pandangan. Pertama, teknologi pendidikan dapat mempermudah dalam memperoleh inormasi dalam menyampaikan materi sehingga aktitas pembelajaran yang dilaksnakan tidak ada kendala khusus pada pembelajaran jarak jauh. Namun, dalam pemerataan pembelajaran atau dalam penyampaian pembelajaran masih terdapat beberapa kendala yang terjadi di beberapa sekolah, guru dan siswanya. Pada masa pandemi saat ini, media yang digunakan ialah berbasis internet, sedangkan banyak yang mengeluh akan susahnya jaringan internet untuk di jangkau, terbatasnya alat yang dimiliki para siswa sampai-sampai ada yang keberatan akan pengeluaran yang digunakan untuk membeli paket data. Jaelani, Fauzi, Aisha, dan Zaqiyah (2020), mengatakan bahwa, belum meratanya diperkenalkan pemanfaatan teknologi sebagai media belajar, seperti laptop, gadget, dan lain sebagainya.

Kedua, teknologi pendidikan menciptakan cangkupan yang sangat luas saat masa pandemi, hal ini memberikan kemudahan pada semua pihak, pada guru maupun siswanya. Dengan menggunakan teknologi pendidikan kita dapat merangkul banyak dan luasnya cakupan. Dari mulai penyampaian pembelajaran, materi pelajaran yang disampaikan, kelancaran dalam penyampaian, hingga pada memudahkan siswa dalam memahami, menerima, dan mengakses pembelajaran. Namun, ada saja pada beberapa tempat yang masih terhalang untuk melacarkan pembelajarannya pada saat pandemi. Permasalahan yang sering terjadi yaitu, kurangnya kreativitas guru ataupun penguasaan penggunaan media yang akan digunakan pada saat pandemi.

Ketiga, teknologi pendidikan memberikan dampak yang bermanfaat bagi para pelaku pendidikan khusunya pendidik. Teknologi pendidikan memberikan fasilitas kepada pendidik dalam berinovasi sehingga membantu jalanya pembelajaran

Keempat, teknologi dapat menggantikan guru. Padahal teknologi pendidikan dapat menjadi bernilai ketika seorang pendidik dapat menggunakannya dengan baik, kreatif, inovatif serta dapat mempermudah siswanya dalam memahami pembelajaran yang disampaikan. dikatakan teknologi dapat menggantikan guru yaitu dari penggunaan media pembelajaran yang diperbolehkan, misal internet. Internet dapat memudahkan siswa dalam mencari informasi, internet juga menyediakan berbagai macam informasi yang dibutuhkan siswa dengan mudah di akses.

\section{Dampak Teknologi Pendidikan dalam Pembelajaran di Masa Pandemi}

Berkembangnya teknologi pendidikan sampai saat ini, memberikan warnawarni dalam proses pembelajaran. Diantara dampak teknolohi pendidikan di masa pandemi yaitu, pertama, terciptanya berbagai platform pembelajaran. Hal ini memberikan kemudahan bagi guru dan peserta didik dalam menjalani proses pembelajaran jarak jauh. Hadirnya platform yang dapat digunakan memberikan pengetahuan dan pengalaman baru pada peserta didik mengenai perkembangan teknologi. Baik aplikasi, web/blog, video, podcast ataupun yang lainnya. Adanya platform belajar seperti ruang guru, zenius, dll dapat menjadi jembatan peserta didik dalam belajar. Memudahkan mereka dalam memahami pembelajaran yang dilakukan dengan tidak tatap muka.

Kedua, teknologi pendidikan memudahkan peserta didik dalam mencari sumber belajar. Melihat dari media pembelajaran yang digunakan saat pandemi ini, peserta didik lebih leluasa dalam mencari sumber belajar. Menggunakan jaringan 
internet dan media yang telah tersedia, peserta didik dapat mengakses sumber belajar yang mereka butuhkan. Namun, apabila penggunaan internet tidak digunakan dengan baik, kemungkinan terburuk ialah peserta didik dapat mengakses hal-hal yang tidak dibutuhkan ataupun merusak moral.

Ketiga, memberi kemudahan bagi guru dalam menyampaikan materi pembelajaran kepada peserta. Dengan adanya teknologi pendidikan, pembelajaran lebih lues dilakukan tanpa harus bertatap muka.

\section{SIMPULAN}

Teknologi Pendidikan adalah suatu proses yang kompleks untuk memecahkan suatu masalah pendidikan yang terjadi dalam proses pembelajaran. Teknolgi pendidikan lebih ke menilai teknik kegiatan pembelajaran ataupun teknis pembelajaran yang dilakukan. Teknologi pendidikan juga dapat sebagai fasiliator dalam pembelajaran dan dapat juga sebagai erbaikan sistem kinerja melalui penciptaan pengelolaan proyrk teknologi pendidikan. Teknologi pendidikan dapat juga sebagai teknik pendukung sistem pembelajaran yang ada dalam pembelajaran. Teknologi pendidikan dapat sebagai penunjang mteri pembelajaran dalam pendidikan sehingga dapat mencapai tujuan yang diinginkan. Teknologi pendidikan sendiri berpengaruh terhadap pembelajaran yang berlangsung untuk menunjang sistem pembelajaran yang dilaksanakan.

Peran teknologi dalam pembelajaran di era pandemi sendiri mengharuskan pendidikan dilakukan dirumah melalui online atau daring. Kegiatan pembelajaran dilakukan secara online atau daring sendiri bertujuan untuk memutuskan tali penyebaran covid-19. Keberhasilan pembelajaran daring tidak hanya dipengaruhi dari peran teknologi saja, tetapi juga dipengaruhi dari kualitas Sumber Daya Manusia. Teknologi tidak akan memberikan pengaruh yang signifikan apabila SDM sebagai operator atau pengguna tidak memiliki pengetahuan serta keterampilan yang baik dalam penggunaan dan pengelolaan teknologi.

\section{DAFTAR PUSTAKA}

Andri, Rogantina Meri. "Peran Dan Fungsi Teknologi Dalam Peningkatan Kualitas Pembelajaran." Jurnal Ilmiah Research Sains 3, no. 1 (2017): 122-29. http://www.jurnalmudiraindure.com/wp-content/uploads/2017/04/PERAN-DANFUNGSI-TEKNOLOGI-DALAM-PENINGKATAN-KUALITASPEMBELAJARAN.pdf.

Arifa, Fieka Nurul. "Tantangan Pelaksanaan Kebijakan Belajar Dari Rumah Dalam Masa Darurat Covid-19." Info Singkat;Kajian Singkat Terhadap Isu Aktual Dan Strategis XII, no. 7/I (2020): 15. http://berkas.dpr.go.id/puslit/files/info_singkat/Info Singkat-XII-7-IP3DI-April-2020-1953.pdf.

Cahyani, Adhetya, Iin Diah Listiana, and Sari Puteri Deta Larasati. "Motivasi Belajar Siswa SMA Pada Pembelajaran Daring Di Masa Pandemi Covid-19." IQ (Ilmu Al-Qur'an): Jurnal Pendidikan Islam 3, no. 01 (2020): 137. https://doi.org/10.37542/iq.v3i01.57.

Handarini, Oktafia Ika, and Siti Sri Wulandari. "Pembelajaran Daring Sebagai Upaya Study From Home (SFH) Selama Pandemi Covid 19." Jurnal Pendidikan Administrasi $\begin{array}{lllllll}\text { Perkantoran } & \text { (JPAP) } & 8, & \text { no. } & 3 & \text { (2020): }\end{array}$ https://journal.unesa.ac.id/index.php/jpap/article/view/8503.

Juanda. "APJII: Indonesia Belum Merdeka Internet." KOMITE.ID, 2020. https://www.komite.id/2020/08/11/apjii-indonesia-belum-merdeka-internet/.

Kemendikbud, Badan Pengembangan dan Pembinaan Bahasa. "KBBI Daring: Pencarian," 2016. https://kbbi.kemdikbud.go.id/. 
Latip, Abdul. "Komunikasi Pada Pembelajaran Jarak Jauh Di Masa Pandemi COVID-19." Edukasi Dan Teknologi 1, no. 2 (2020): 108-9. https://www.researchgate.net/profile/Abdul_Latip/publication/341868608_PERAN_LIT ERASI_TEKNOLOGI_INFORMASI_DAN_KOMUNIKASI_PADA_PEMBELAJARA N_JARAK_JAUH_DI_MASA_PANDEMI_COVID19/links/5ed773c245851529452a71e9/PERAN-LITERASI-TEKNOLOGIINFORMASI-DAN-KOMUNIKASI.

Lestari, Sudarsri. "Peran Teknologi Dalam Pendidikan Di Era Globalisasi." Edureligia; Jurnal Pendidikan Agama Islam 2, no. 2018$)$ : 95-96. https://doi.org/10.33650/edureligia.v2i2.459.

Miarso, Yusufhadi. Menyemai Benih Teknologi Pendidikan. Jakarta: Prenadamedia Group, 2016.

https://books.google.co.id/books?id=rhVNDwAAQBAJ\&printsec=frontcover\&dq=buku +menyemai+benih+teknologi+pendidikan\&hl=id\&sa=X\&ved=2ahUKEwiTh_ez-3sAhWDILcAHfoLCjgQ6AEwAHoECAUQAg\#v=onepage\&q=buku menyemai benih teknologi pendidikan\& $\mathrm{f}=$ false.

Padmini, Kristiana Hesti, and Brigitta Putri Atika Tyagita. "Teknologi Pendidikan Sebagai Pembelajaran Kompetitif Untuk Meningkatkan Prestasi Siswa : Studi Kasus Di Salah Satu SMA Di Salatiga.” In Prosiding Seminar Nasional Pendidikan, 60. Surakarta, 2015. https://media.neliti.com/media/publications/171192-ID-teknologi-pendidikan-sebagaipembelajara.pdf.

Pribadi, Benny A. "Peranan Teknologi Pendidikan Dalam Meningkatkan Kualitas Pembelajaran." In Optimalisasi Peranan Teknologi Pendidikan Dalam Peningkatan Kualitas Pembelajaran, 2-3. Padang: Universitas Terbuka Repository, 2011. http://repository.ut.ac.id/7265/1/Peranan Teknologi Pendidikan dalam.pdf.

Putro, Khamim Zarkasih, Muhammad Adly Amri, Nuraisah Wulandari, and Dedek Kurniawan. "Pola Interaksi Anak Dan Orangtua Selama Kebijakan Pembelajaran Di Rumah." Fitrah: Journal of Islamic Education (FJIE) 1, no. 1 (2020): 126. https://jurnal.staisumateramedan.ac.id/index.php/fitrah/article/view/12/8.

Rahayu, Titik, Syafrimen Syafril, Ismail Suardi Wekke, and Rita Erlinda. "Teknik Menulis Review Literatur Dalam Sebuah Artikel Ilmiah," no. September (2019). https://doi.org/10.31227/osf.io/z6m2y.

Saleh, Meylan. "Merdeka Belajar Di Tengah Pandemi Covid-19." In Prosiding Seminar Nasional Hardiknas, 2020. http://proceedings.ideaspublishing.co.id/index.php/hardiknas/article/view/8/8.

Suni Astini, Ni Komang. "Tantangan Dan Peluang Pemanfaatan Teknologi Informasi Dalam Pembelajaran Online Masa Covid-19.” Cetta: Jurnal Ilmu Pendidikan 3, no. 2 (2020): 243. https://doi.org/10.37329/cetta.v3i2.452.

Tahir, M. Yusuf. "Peranan Teknologi Pendidikan Dalam Peningkatan Mutu Pendidikan." In Prosiding SIDKUN 2016: Seminar Islam Dan Kelestarian Ummah Peringkat Serantau, 484-89. Kedah: Pusat Pengaji Bahasa, Tamadun dan Falsafah, Kolej Sastera Sains, د قالات مجمو عه= Universitas Utara Malaysia, 2016. http://www.ghbook.ir/index.php?name

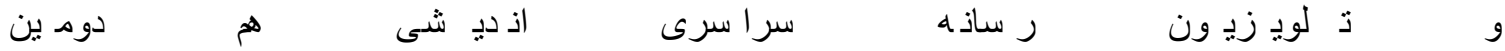
س كو لاريـ سم دن \&option=com_dbook\&task=readonline\&book_id=13629\&page=108\&chkh ashk=03C706812F\&Itemid=218\&lang=fa\&tmpl=component. 